Article received on September $25^{\text {th }} 2019$

Article accepted on November $28^{\text {th }} 2019$

UDC: 78.071.1 Кардју К.

78.071.1 Рзевски Ф.

\author{
Radoš Mitrović* \\ University of Arts in Belgrade \\ Faculty of Music \\ Department of Musicology
}

\title{
IMPROVISED MUSIC AS SOCIALLY ENGAGED ART: POETICS OF CARDEW AND RZEWSKI ${ }^{1}$
}

\begin{abstract}
In the light of the social turmoil in 1968, some composers have singled out advocating the greater involvement of musicians, i.e. music in the social movement. Cornelius Cardew and Frederic Rzewski, among others, believed that improvised music provides the opportunity for creating socially engaged art. However their concepts differed. While Cardew stayed with the idea of controlled improvisation, implemented through the Scratch Orchestra, Rzewski demanded completely free improvisation in his Parma Manifesto. In this paper I shall problematize the relationship of poetics behind the Scratch Orchestra and the Parma Manifesto in the light of the social situation of 1968, their crucial differences and their common idea of the democratization of avant-garde music.
\end{abstract}

Keywords: Cornelius Cardew, Frederic Rzewski, Avant-garde, the Scratch Orchestra, Improvised Music, the Parma Manifesto

Adorno argued that music should be a reflection of reality, i.e. its structure had to match the character of the times in which it was created. We can say that his attitude was the opposite of socialist realism, or revolutionary romanticism as it was called by Zhdanov, which included the idea of art which with its content has to show the utopian vision of a communist world. Adorno

\footnotetext{
* Author contact information: radosh.mitrovic@gmail.com

1 The article was delivered at the international conference Musical Legacies of State Socialism (24-26 September 2015, in Belgrade, Serbian Academy of Sciences and Arts) with the title Improvised music as a symbiosis of avant-garde experience and socialist realism in the poetics of Cardew and Rzewski.
} 
called socialist realism Soviet claptrap, while those who defended this artistic expression, like Lukach, believed that Adorno "expressed only the reality of late capitalist societies and Western imperialism: they expressed a decadent social order in decline". ${ }^{2}$

Both of these views of art function as belonging to the leftist political agenda, although they are actually completely opposite. However, apart from these two points of view about the relationship between art and social engagement, a third side may be registered. It can be found in the music of John Cage, which often with its structure and mode of organization simulates the potential of achieving the ideal social system. Therefore, it is a symbolic representation of an ideally perceived social order, realized in the framework of the microstructural organization of artwork. In this context Richard Kostelanetz writes the following in his essay on Cage: "What makes Cage's art special, and to my senses politically original, is that his radical politics were expressed in decisions not of content but of form (....) in the form of his art, in the form of performance, it is a representation of an ideal polity". ${ }^{3}$

He finds Cage's libertarian anarchism in his relations with the hierarchy in music pieces, which was never centralized, but always based on democratic principles and equality. Kostelanetz believed that this can be observed in its egalitarian relation to instruments within the ensemble or media, which can be seen for instance, in the work Credo in US. Also, this critic mentions Cage's book Notations from 1968, in which various compositions of different authors were collected non-hierarchically in a collection without the editor's label. Finally, Cage's anarchism became explicit in his later work, when he turned to Henry Thoreau and the text on civil disobedience. The basic ideas of this philosopher exposed in his book On the Duty of Civil Disobedience are connected with the anarchistic ideological platform. Thoreau begins his text with the words: "I heartily accept the motto that government is best which governs least; and I should like to see it acted up to more rapidly and systematically. Carried out, it finally amounts to this, which also I believe - That government is best which governs not at all; and when men are prepared for it, that will be the kind of government which they will have". ${ }^{4}$

2 James Hellings, Adorno and Art, Aesthetic Theory Contra Critical Theory, Basingstoke, Palgrave Macmillan, 2014, 31.

3 Richard Kostelanetz, The Anarchist Art of John Cage: http://sterneck.net/john-cage/ kostelanetz/index.php, accessed: 24.08.2018.

4 Henry David Thoreau, Civil Disobedience: http://xroads.virginia.edu/ hyper2/thoreau/civil.html, accessed: 24.08.2018. 
This very passage is cited in Cage's essay: The Future of Music. He applies these ideas to music, suggesting that, in the future, no more will there be the despotic rule of the composer in the music world. On the contrary, the accent will be placed on collective musicianship as the highest form of radical democracy. Cage concludes the text with the remark: "By creating musical situations which are analogies to desirable social circumstances which we do not yet have, we make music suggestive and relevant to the serious questions which face Mankind". ${ }^{5}$

So, unlike Adorno, whoever believed that art should provide, through its own structures, a true picture of social reality, but also unlike socialist realism, which involved the creation of art that substantially provides an idealized vision of the present, Cage actually believed in a combination of the two - music structure should reflect an ideal social order. However, it is interesting that Cage, primarily under the influence of Zen, was opposed to free improvisation, although it represents the realization of the mentioned analogy between the organization of music and the desired social system. In this context, Cage's reaction when he heard that Leonard Bernstein was to present his work Atlas Eclipticalis, among the works of Morton Feldman (...Out of "Last Pieces") and Earle Brown (Available Forms II), with the New York Philharmonic in 1964, and when the conductor announced that the orchestra would also perform the free improvisation as a comment on their compositions was very interesting. Referring to Bernstein, Cage begged him not to improvise on the concert. He thought that improvisation is "free play", and that it is not something that he is doing in his music. ${ }^{6}$

Apart from Zen philosophy and the idea of separation from the ego, as a precondition for the creation of pure art, Cage's attitude is associated with the opinion that this improvised music involves a kind of artistic struggle for power in the collective performing of music. For Cage, improvisation, especially group improvisation, is not based on communication, but also on dominance and it is, therefore, not a desirable artistic means, i.e. musical form. However, although Cage was attached to this attitude whereby he categorical-

\footnotetext{
5 Ibid., 183.

6 Cage said that: "Improvisation is not related to what the three of us are doing in our works. It gives free play to the exercise of taste and memory, and it is exactly this that we, in differing ways, are not doing in our music". Acc. to: Sabine M. Feisst, John Cage and Improvisation - An Unresolved Relationship, http://www.hestories.info/john-cage-and-improvisation--an-unresolved-relationship.html, accessed: 20.08.2018.
} 
ly rejected the concept of free improvisation, it is paradoxical that he would make the greatest impact on the development of freely improvised music in Europe. It is not about aleatoric, but about improv collectives that appeared in the 1960s. Three such collectives are very important: the AMM, the Musica Elettronica Viva collective (MEV), and the Scratch Orchestra, which included two also important composers for the development of improvised music: Cornelius Cardew and Frederic Rzewski.

The AMM collective was founded in 1965 as an ensemble based on a non-hierarchical form of organization and was specialized in free improvisation. Each performance was a product of collective engagement, with no scores or leader. That would change with the arrival of Cornelius Cardew in 1966, who began his performance career as a pianist and cellist, changing the way in which the ensemble functioned. As an established avant-garde composer, who entered improvised music from strict serialism, Cardew became the leader of the ensemble, writing and dedicating his own works to it. The first work written for this ensemble was Sextet - The Tiger's Mind. It is a prose composition, based on two short, symbolic and anti-narrative texts: Daypiece and Nightpiece. Almost surrealist texts are linked to a quasi-story about the relationship between nature and mind. Cardew differentiates six characters whose roles, in the first phase of the artistic process, the musicians need to take on. The characters can be divided into categories of - living: Amy, the tiger, wood; inanimate: wind; and abstract: the circle and the mind. The suggestion that it is not a pointless narrative, but the dream vision of a certain Amy, is given by Cardew himself in the score, noting that Amy is the only character whose role cannot be doubled, i.e. the music can be represented only by a single performer. On the other hand, the question arises about who dreams about whom: Amy about the tiger, or the tiger about Amy - which is shown by the composition title. The idea of such paradoxical dramatic settings can be associated with Cardew's intense interest in Chinese philosophy, in this case specifically for Zhuang Zhou, and his parable about a man and a butterfly. In accordance with this philosopher's thinking that nothing is permanent, and that transformation is the key for each course of life, Cardew does not build a full work. On the contrary, his work is based on the continuous process of constant changing. For the first time, the work should be carried out so that each performer plays the section linked to one character - in each subsequent interpretation the rules may change. So Cardew notes:

each musician may select his own role and allocate the other five roles without telling the other players. Alternatively, each player may select his own role and 
allocate the other five in the course of playing, as required by the performance of his own role. Logically, after this stage it is no longer so important for there to be six players. When there are more than six players the characters may be duplicated or multiplied as often as necessary. ${ }^{7}$

Cardew, thus, from the beginning tried to bring a certain degree of organization, or control to the improvisation. Although it is an experimental form of music-making, the presence of the poetic text, which includes the distribution of roles within the ensemble, already makes the real stratification within improvisation. Cardew himself remains the author of the work, and therefore the accent was not on the free improvisation of the ensemble, but on monitoring the composer's ideas, no matter how elusive they may be in the score. Cardew leaves room for the artists' independent decision-making about their role and the content of the performance, but essentially, the improvisation in The Tiger's Mind comes down to the interpretation, which was not the original idea of the ensemble. Another work is symptomatic in the context of speaking about Cardew's relation to improvised music, and it is Treatise. It is a graphic score, which was created in the period from 1963 to 1967, and it is the result of Cardew's graphic design experience and interest in the philosophy of Ludwig Wittgenstein, more specifically in his text Tractatus Logico-Philosophicus. Cardew was actually trying to merge Wittgenstein's ideas about the world and the manner of his perception into an artistic concept, which actually functions on a similar principle as in the work The Tiger's Mind. ${ }^{8}$

Namely, as Cardew requires that performers choose roles, i.e. to rationalize and organize the seemingly surrealistic text, breaking it down to the facts, in Treatise it means reducing the graphical score to a set of norms and rules of improvisation in functioning. So, relying on Wittgenstein's ideas, he actually wants to establish order, i.e. the world, by the strict organization of elements that constitute the totality of facts. The performers themselves have the freedom of determining the meaning of the graphics that, in their conception, acquire the role of various parameters for determining the tempo,

7 Cornelius Cardew, Sextet - The Tiger's Mind, (score): https://www.jstor.org/stable/951366 ?seq=1\#page_scan_tab_contents, accessed: 24.08.2018.

8 The first few lines of Wittgenstein's text are the key to understanding these works: "The world is everything that is the case. 1.1 The world is the totality of facts, not of things. 1.11 The world is determined by the facts, and by these being all the facts. 1.12 For the totality of facts determines both what is the case, and also all that is not the case". Ludwig Wittgenstein, Tractatus Logico-Philosophicus, London, Kegan Paul, 1922, 25. 
rhythm, dynamics, or the melodic movement. Therefore, a certain kind of democratic organisation of interpretation is possible, based on the independent and group determination of the interpretation's limits. It is not about anarchy, or total democratic order within the music, but about a strictly regulated system based on hierarchy. The system provides the freedom of decision, as long as everything is within the set frameworks that enable the functioning of the entire improvisation collective. Cardew's left-oriented ideological position can already be observed in such ideas. This position was implicit until the composition Great Learning. In Great Learning, which is based on seven paragraphs of Confucius' text of the same title, the composer for the first time explicitly addresses the issue of the organization of society, which would later become the core of his music, influenced by socialist realism. Confucius' text contains such maxims, for instance:

Things being investigated, knowledge became complete. Their knowledge being complete, their thoughts were sincere. Their thoughts being sincere, their hearts were then rectified. Their hearts being rectified, their persons were cultivated. Their persons being cultivated, their families were regulated. Their families being regulated, their states were rightly governed. Their states being rightly governed, the whole kingdom was made tranquil and happy. ${ }^{9}$

Therefore, it is not a purely metaphysical and philosophical text, but also, in a way, a practical text on the achievement of happiness within the community, i.e. state. In the score of Cardew's work, the author quite strictly organizes the parameters, leaving space for a specific kind of controlled improvisation, which is in a symbolic sense connected with the textual template. The basis of this work, divided into seven parts related to seven paragraphs of Confucius' text, in musical terms, is based on the idea of the common music-making through the interactive performers' response. An example of this is the seventh part written for the choir, which is based on the principle that each performer has to choose the starting pitch, managing his own melody line in accordance with the tones sung by his colleagues.

Each chorus member chooses his or her own note (silently) for the first line ("IF" eight times). All enter together on the leader's signal. For each subsequent line choose a note that you can hear being sung by a colleague. It may be necessary to move to within earshot of certain notes. The note, once chosen, must be carefully retained. Time may be taken over the choice. If there is no note, or only the note

9 Confucius, The Great Learning, http://classics.mit.edu/Confucius/learning.html, accessed: 24.08.2018. 
you have just been singing, or only a note or notes that you are unable to sing, choose your note for the next line freely. Do not sing the same note on two consecutive lines. ${ }^{10}$

So, as in the two previous works, Cardew builds the composition by offering its draft organization and functioning, leaving limited freedom to the performers themselves. The aim is to achieve an order based on the principles of mutual cooperation and rules of conduct.

The Great Learning was the first work dedicated to the newly founded ensemble, the Scratch Orchestra. It is an ensemble which was created in 1968-69, with the initial role of performing the Great Learning. However, the ensemble expanded rapidly to include new members, many of whom were amateurs. The Scratch Orchestra quickly became very socially engaged, finding itself in the position of the political left. This composition was based on the ideas of subversion of the existing bourgeois, capitalist system, which actually was in accordance with the time of its occurrence, when the Left in Europe became stronger. His subversiveness was reflected:

in the organization, which was destroying the hierarchy, encouraging artistic activities of all those who were interested, even if they were self-taught artists; in the manner of concert realization aimed at attracting a wider audience, not just a narrow circle of fans, which was characteristic of the avant-garde;

in the social engagement of the orchestra, including performances on the occasion of various social events, including those concerning the protection of the environment, and political events, including the Chicago 8 Protest concert held in support of eight arrested leaders of the anti-war protests in 1968 and the Nuclear Disarmament Rally.

Cardew formulated the functioning system of the orchestra in the Draft Constitution in 1969 when the orchestra became a more strictly organized structure with clear objectives and methods of social action. As in Cardew's compositions, this draft also emphasises the democratic organization of the collective. ${ }^{11}$

10 Cornelius Cardew, The Great Learning, (score), https://www.newmusicnewcollege. org/PDFs/Cardew_score.pdf, accessed: 24.08.2018.

11 In the Draft Constitution of Scratch Orchestra, Cardew noted: “The Scratch Orchestra intends to function in the public sphere, and this function will be expressed in the form of - for lack of a better word - concerts. In rotation (starting with the youngest), each member will have the option of designing a concert. If the option is taken up, all details 
Cardew also emphasises that every member of the collective must have his own "notebook or (scratchbook) in which he notates a number of accompaniments, performable continuously for indefinite periods". ${ }^{12}$ Also those notebooks should contain sketches of individual scientific, artistic research projects. ${ }^{13}$

In their spare time, each member had to be engaged in making their own musical instrument, and another curiosity was the fact that members had to make proposals for the formulation of the program of popular classical music, which would also have been performed at concerts. Known works of classicism and romanticism, however, would not be rehearsed, but played as they were remembered, with the possibility of additional improvisation and deconstruction of musical material. By means of this unusual provision, Cardew clearly wanted to bring a special kind of revolutionary energy to the ensemble that would, by this act, actually directly exercise the subversion of the great bourgeois musical tradition. ${ }^{14}$

of that concert are in the hands of that person or his delegates; if the option is waived the details of the concert will be determined by random methods, or by voting (a vote determines which of these two)". Cornelius Cardew, "A Scratch Orchestra: Draft Constitution", The Musical Times, Vol. 110, No. 1516 (June, 1969), 617.

12 Ibid., 617.

13 Cardew emphasised: "Research should be through direct experience rather than academic: neglect no channels. The aim is: by direct contact, imagination, identification and study to get as close as possible to the object of your research. Avoid the mechanical accumulation of data; be constantly awake to the possibility of inventing new research techniques. The record in the Scratchbook should be a record of your activity rather than an accumulation of data. That means: the results of your research are in you, not in the book". Ibid., 619.

14 Rod Eley, the leader of the Communist Party of Ireland, in his study The History of Scratch Orchestra, interpreted Cardew's draft constitution as follows:

"The Draft Constitution was the last word in liberalism. 'Anything goes' was the policy and any discussion of the merits of a proposal was outlawed. However, this had a beneficial aspect, for the Constitution stressed the importance of actually organising activities. This was a break with sterile and detached preoccupations, with 'criticism', which paralyse and degenerate most bourgeois art movements. In this atmosphere a kind of collective confidence grew out of the common activity of work together. Instead of one or two individuals doing everything, new and younger people were encouraged to put their ideas into practice, and this released a lot of initiative. By encouraging the active participation of everyone, individualism was opposed and this created fertile conditions for the introduction of the new ideas of Marxism-Leninism. The respect for real work, 
It is evident that the Scratch Orchestra was the start of Cardew's intensive study of Marxism, which would, combined with the previously mentioned interest in Chinese philosophy, influence the composers turning to Maoism in the early seventies, as well as to socialist realism.

If we go back to the initial thesis in which we discussed the idea of manifesting political views through the organization of musical structure, one can draw a parallel between Cardew's ways of organizing forms and Maoism. This can be seen in the fact that the organisation of all works, including the organization of the Scratch Orchestra, was based on an order that implied a vision of centralized democracy. This is precisely the kind of system which Mao himself advocated. He was for "democratic centralism" thinking that it was the way to avoid concepts of organisation that were not good for the discipline of people - mainly "ultra-democracy" and the laissez-faire system. ${ }^{15}$

Although they were associates, Frederik Rzewski, unlike Cardew, in the sixties, before he began writing politically inspired music, promoted the principle of completely free improvisation. The MEV collective, founded in 1966, to which Rzewski belonged, was established as an ensemble whose work was based on spontaneity, which is reflected in every aspect of his work: rehearsals, performances and the organization of improvisation. Unlike Cardew,

actual leadership and for putting ideas into practice made many members receptive to the Marxist-Leninist principle of integrating theory with practice in order to change society, and working as a collective". Cornelius Cardew, Stockhausen Serves Imperialism, UBU Classics, 2004, 19.

15 In the study The Role of the Chinese Communist Party in the National War, Mao Tsetung wrote: "In the present great struggle, the Chinese Communist Party demands that all its leading bodies and all its members and cadres should give the fullest expression to their initiative, which alone can ensure victory. This initiative must be demonstrated concretely in the ability of the leading bodies, the cadres and the Party rank and file to work creatively, in their readiness to assume responsibility, in the exuberant vigour they show in their work, in their courage and ability to raise questions, voice opinions and criticize defects, and in the comradely supervision that is maintained over the leading bodies and the leading cadres. Otherwise, 'initiative' will be an empty thing... education in democracy must be carried on within the Party so that members can understand the meaning of democratic life, the meaning of the relationship between democracy and centralism, and the way in which democratic centralism should be put into practice. Only in this way can we really extend democracy within the Party and at the same time avoid ultra-democracy and the laissez-faire which destroys discipline". Mao Tse-tung, The Role of the Chinese Communist Party in the National War, 1938, https://www.marxists.org/reference/archive/ mao/selected-works/volume-2/mswv2_10.htm\#p9, accessed: 24.08.2018. 
Rzewski was more sympathetic to anarchist ideas, although they were close friends. Rzewski was actually closer to the whole hippie movement, collaborating on joint events with collectives such as the Living Theatre. Like them, who described their events as Beautiful Non-Violent Anarchist Revolution, Rzewski also strived to create music events which would be based on absolute democracy. Emphasis was on the interaction among the members, as well as the ensemble and the audience, where all the possible ways of playing the instruments were available, as well as interventions by the listeners. The aim was to create an egalitarian social system, even during the concert, which would serve as a model to larger, more revolutionary system changes. As pointed out by Rzewski:

The MEV wishes to explore a possibility for music, which Western music has denied Itself for so long, of a new oral tradition, based on the self determination of free individuals within a freely constituted collective. The work is a search for the conditions which must be created 'if human beings are ever to reach the stage of singing peace on sight, without rehearsal. ${ }^{16}$

The MEV argued for a deconstruction of the existing relationships within classical music which was the counterpart of the social order dominated by hierarchy. Thus, they wanted to abolish the differences between the composer, the performer and listener. The idea was that anyone could assume any of the aforementioned roles, so certain artistic ideals could jointly be realized. The artistic ideal was really the social ideal. Rzewski thought that the key idea behind the MEV was that it had to "liberate the audience". ${ }^{17}$

Rzewski summed up all these requirements in the so-called Parma Manifesto, published in 1968, initiated by the obstruction of the city authorities who did not allow the MEV collective and the Living Theatre's event to take place in Parma. This manifesto was aimed at pointing out the problems of the capitalist system and the state, which was unable to respond with its repressive apparatus and its economy to the needs of individuals. Through anti-war

16 In that sense, Rzewski wrote: "In 1968, after having liberated the performance, the MEV set out to liberate the audience. If the composer had become one with the listener, the player had to become one with the listener (...) Music is a creative process in which we can all share, and the closer we can come to each other in this process, abandoning esoteric categories and professional elitism, the closer we can all come to the ancient ideal of music as universal language". Frederic Rzewski, "Musica Elettronica Viva”, The Drama Review: TDR, 14/1, 1968, 93.

17 Ibid., 94. 
and humanistic rhetoric, Rzewski called for the creation of alternative spaces for social functioning, which would be created through dialogue and in which the artist could make a significant contribution. Artists had to create a new form of multidirectional communication, providing freedom of thought and action for all participants. The art form that would make this possible had to be freed from the burden of the past. ${ }^{18}$ Finally, Rzewski add that: "Improvisation is the art of creating out of nothing: a lost art form. It is necessary to rediscover this form and re-invent its rules, now. It is necessary to embark upon a disciplined search for a new harmony. Harmony is a process in which the speaker and listener agree to communicate". ${ }^{19}$

Speaking of this manifesto in his later text, Rzewski clarified its position, concluding that improvisation was an experimental form of social practice that heralded a future utopian society based on the complete realization of anarchy, i.e. a society without money, government or a repressive state apparatus.

The seventies brought the alienation of Rzewski and Cardew from the idea of engaged music which generates subversiveness by its very structure, and adherence to the view that the content is more important than the musi$\mathrm{cal}$ form. Both were distanced from their own positions from the sixties. Rzewski still performs with MEV collective, which renounced former political pretensions, but believes that the problem of MEV ensemble was that it was in the sixties too influenced by the hippie movement and the artistic trend.

In the seventies, Cardew not only distanced himself from his own early opus, but also from the former music models, writing texts: John Cage: Ghost or Monster? or Stockhausen Serves Imperialism. He condemned his attachment to Confucius, whom he accused of being the defender of a decadent and dying system. ${ }^{20}$ In accordance with the communist attitude of self-criticism, Cardew condemned his bourgeois manners, reflected in his participation in the creation of improvising collectives. The first opportunity for such sharp self-criticism presented itself to him at a symposium in Rome in 1972, which

\footnotetext{
18 Rzewski held the opinion that "[d]ecisions of this art must be born from marrying the moment, the creative moment in which the organism approaches reality so immediately that it is blessed with the perception of the highest possible future, which is its natural course toward joy. Such an art form must be improvised, free to move in the present without burdening itself with the dead weight of the past". Frederic Rzewski, Parma Manifesto, http://giorgiomagnanensi.com/parma-manifesto/, accessed: 23.08.2018.

19 Ibid.

20 See: Cornelius Cardew, Stockhausen Serves Imperialism, op. cit., 93-105.
} 
was dedicated to the problems of modern musical notation. Instead of talking about innovations he introduced into his composition Treatise with respect to graphic notation, Cardew talked about his fall into the avant-garde trap creating avant-garde music that is part of imperialist culture. In that sense, talking about Stockhausen's piece Refrain, Cardew was under the impression that avant-garde music was

a part of the cultural superstructure of the largest scale system of human oppression and exploitation the world has ever known: imperialism. The way to attacking the heart of that system is through attacking the manifestations of that system, not only the emanations from the American war machine in Vietnam, not only the emanations from Stockhausen's mind, but also the infestations of this system in our own minds, as deep-rooted wrong ideas. And we must attack them not only at the superficial level, as physical cruelty or artistic nonsense or muddled thinking, but also at the fundamental level for what they are: manifestations of imperialism. $^{21}$

\section{Works cited}

Cardew, Cornelius: Sextet - The Tiger's Mind (score), taken from:

https://www.jstor.org/stable/951366?seq=1\#page_scan_tab_contents, accessed: 24.08.2018.

Cardew, Cornelius: The Great Learning (score),

https://www.newmusicnewcollege.org/PDFs/Cardew_score.pdf, accessed: 24.08.2018.

Cardew, Cornelius: "A Scratch Orchestra: Draft Constitution", The Musical Times, Vol. 110, No 1516 (Jun, 1969), 617-619.

Cardew, Cornelius: Stockhausen Serves Imperialism, UBU Classics, 2004.

Confucius: The Great Learning, http://classics.mit.edu/Confucius/learning.html, accessed: 24.08.2018.

Feisst, Sabine: M, John Cage and Improvisation - An Unresolved Relationship: http://www. hestories.info/john-cage-and-improvisation--an-unresolved-relationship.html, accessed: 20.08.2018.

Hellings, James: Adorno and Art, Aesthetic Theory Contra Critical Theory, Basingstoke, Palgrave Macmillan, 2014.

Kostelanetz, Richard: The Anarchist Art of John Cage: http://sterneck.net/john-cage/kostelanetz/index.php, accessed: 24.08.2018.

Rzewski, Frederic: "Musica Elettronica Viva", The Drama Review: TDR, 14/1, 1968, 9297.

Rzewski, Frederic: Parma Manifesto, http://giorgiomagnanensi.com/parma-manifesto/, accessed: 23.08.2018.

21 Ibid., 47. 
Thoreau, Henry David: Civil Disobedience: http://xroads.virginia.edu/ hyper2/thoreau/ civil.html, accessed: 24.08.2018.

Wittgenstein, Ludwig: Tractatus Logico-Philosophicus, London, Kegan Paul, 1922.

The Role of the Chinese Communist Party in the National War, 1938, https://www.marxists.org/reference/archive/mao/selected-works/volume-2/ mswv2_10.htm\#p9, accessed: 24.08.2018.

\section{Summary}

In the light of the social turmoil in 1968, some composers have singled out advocating the greater involvement of musicians, i.e. music in the social movement. Cornelius Cardew and Frederic Rzewski, among others, believed that improvised music provides the opportunity for creating socially engaged art. However their concepts differed. While Cardew stayed with the idea of controlled improvisation, implemented through the Scratch Orchestra, Rzewski demanded completely free improvisation in his Parma Manifesto. In this paper I shall problematize the relationship of poetics behind the Scratch Orchestra and the Parma Manifesto in the light of the social situation of 1968, their crucial differences and their common idea of the democratization of avant-garde music. The Parma Manifesto, written in 1968, proclaimed the creation of socially engaged music based on improvisation - a form that contains the possibility for communication between the subjects: between the members of the ensemble, or between the musicians and the audience. This type of communication through improvisation is not supposed to be governed by any type of restraining laws or guidelines. In this context Rzewski states that: decisions (of improvisation) cannot be governed by structures and formulas retained from past moments of inspiration, which it is content to re-arrange and re-interpret. He thinks that improvisation is a form of art that can free the individual of artistic, and thus, social pressure, equating all participants in this act. On the other hand, Cornelius Cardew held that improvisation offers the possibility of creating a non- hierarchical collective, which, however, must contain some minimum form of self-management. In this sense, we can say that the two composers were on opposite sides of the issue of the relationship between freedom and control, offering different concepts of improvised music. However, their goals, inspired by the Left political agenda, were actually the same. 